Papers and Proceedings of the Royal Society of Tasmania, Volume 118, 1984

(ms . received 6.IX.1983)

\title{
THE OCCURRENCE OF THE SOUTHERN BOTTLE-NOSED WHALE IN TASMANIAN WATERS
}

by G. Davis and E.R.Guiler

Bellerive, Tasmania and Sandy Bay, Tasmania

(with one table and one text-figure)

ABSTRACT

DAVIS, G. and GUILER, E.R., 1984 (31 viii): The occurrence of the southern bottle-nosed whale in Tasmanian waters. Pap. Proc. R. Soc. Tasm., 118: 103-107.

https://doi.org/10.26749/rstpp.118.103 ISSN 0080-4703.22 Hill Street, Bellerive, Tasmania and 8 Tiersen Place, Sandy Bay, Tasmania.

The first record of this species from Tasmania brings the total number of ziphiids from Tasmanian seas to eight. Details are given of the measurements of the skull.

\section{INTRODUCTION}

The Southern Bottle-nosed Whale, Hyperoodon planifrons Flower, was described from an imperfect skull from northwestern Australia (Flower 1882). Since that time only 15 further specimens have been reported, three of these being on Australian coasts, but in only five instances was the skull recovered, and only one of these was measured according to the criteria established by Moore (1972).

Moore (1968) considered that the southern representative of this genus differed so greatly from the genotype $H$. ampulzatus, from northern waters that he assigned $H$. planifrons to the sub-genus Erasercetus.

\section{THE SPECIMEN}

The current record is based on an old skull from Ocean Beach, Strahan, which was found in 1981 by Mr M. Schulz, Geography Department, Monash University, who placed it in the dunes. The skull already was dry and weathered. He subsequently relocated the skull and notified Mr H. Wapstra, Tasmanian National Parks and Wildlife Service, who informed one of us (G.D.) who recovered the skull.

It is our opinion that the skull was deposited at least ten years ago as there is no trace of oil and rootlets have penetrated some of the sutures. Moss was found growing on some of the exposed parts of the skull.

Measurements of the skull are given in table 1 which also contains the dimensions that are known for the other $H$. planifrons skulls. The skull is illustrated (fig. 1). The Tasmanian specimen is slightly larger than the South African or South Georgia specimens but smaller than the South Australian material. Fraser (1945) suggested that both sexes were about the same size when adult and that the South American material in the Museo de la Plata described by Moreno (1895) was juvenile. The Tasmanian specimen supports his views as all of Moreno's material as measured by Fraser is much smaller than the present specimen.

Some of the relative dimensions of the Tasmanian specimen are different from those quoted by Moore for the South African material, notably the length from the apex of the ros trum to the most posterior extremity of the maxilla is proportionally greater than might be expected as are also the measurements from the rostrum to the superior nares, the premaxillary crest and the pterygoid sinus. Since the other rostral measurements are not proportionally greater this difference is due to a difference in the relative lengths of the pterygoids of the several specimens. 
TABLE 1

THE SKULL OF THE TASMANIAN AND OTHER SPECIMENS OF HYPEROODON PLANIFRONS.

Measurements (mm) following the system of Moore (1972). The South African specimen of Tietz (1966) was reported in Moore (1972) and the South Australian specimen is that of Hale (1931).

1 Apex of rostrum to most posterior part of occipital condyles $\begin{array}{llll}1 & 2 & 3 & 4\end{array}$

2 Apex of rostrum to transverse plane at apices of anterior orbital notches

3 Apex of rostrum to anterior margin of inferior nares

4. Apex of rostrum to free apex of pterygoid bone

5 Apex of rostrum to anterior apex of pterygoid

6 Apex of rostrum to apex of maxillae between pterygoids

7 Apex of rostrum to apex of most posterior extremity of either maxilla

8 Apex of rostrum to anterior margin of superior nares

9 Apex of rostrum to anterior part of premaxillary crest

10 Apex of rostrum to posterior part of temporal fossa

12 Apex of rostrum to anterior part of pterygoid sinus

13 Greatest length of temporal fossa

14 Greatest length of orbit

15 Greatest length of right nasal on synvertex of skull

16 Length of nasal suture

17 Greatest breadth of skull across postorbital frontal processes

18 Greatest breadth of skull across zygomatic processes

19 Greatest breadth of skull across centre of orbits

20 Least breadth across posterior margin of temporal fossae

21 Greatest lateral spread of occipital condyles

22 Greatest width of wider occipital condyle

23 Greatest length of longer occipital condyle

24 Greatest width of foramen magnum

25 Greatest lateral spread of exoccipital bones

26 Greatest lateral spread of nasal bones

27 Greatest distance between maxillary crests

28 Greatest extension of right premaxilla posterior to right nasal

29 Greatest spread of premaxillary crests

30 Narrowest spread of smooth part of premaxillae between nasals

31 Greatest spread of premaxillae anterior to no.30

32 Greatest spread of premaxillae at middle of rostrum

33 Greatest width of rostrum at apices of antorbital notches

34 Greatest width of rostrum at apices of prominential notches

35 Greatest width of rostrum at midlength of rostrum

36 Greatest depth of rostrum at midlength of rostrum

37 Greatest transverse width of superior nares

38 Inside width of inferior nares at apices of pterygoid notches

40 Greatest width of temporal fossa perpendicular to long axis

41 Least distance between main (anterior) maxillary foramina

42 Least distance between premaxillary foramina

43 Posteromesial margin of $1 \mathrm{eft}$ maxillary foramen to apex left antorbital tubercle

44 Greatest length of vomer at surface of palate

$\begin{array}{rrrc}1300 & 1210 & 1193 & 1391 \\ & & & \\ 780 & 715 & 688 & 666 \\ 1020 & 855 & & - \\ 980 & 922 & 948 & 1150 \\ 690 & 596 & & - \\ 880 & 720 & & - \\ & & & \\ 1240 & 1080 & & - \\ 1050 & 890 & & - \\ 1060 & 895 & & - \\ 1300 & 1130 & & - \\ 820 & 595 & & - \\ 215 & 210 & & - \\ 200 & 156 & & - \\ 50 & 85 & & - \\ 105 & 100 & & - \\ 660 & 636 & & - \\ 720 & 600 & 601 & 665 \\ 590 & 628 & & - \\ 500 & 350 & & - \\ 190 & 204 & & 237 \\ 100 & 85 & & - \\ 83 & 141 & & 174 \\ 59 & 85 & 60 & 60 \\ 520 & 473 & & - \\ 56 & 90 & & - \\ 88 & 88 & & - \\ 9 & 30 & & - \\ 330 & 265 & & - \\ 155 & 181 & & - \\ 200 & 170 & & 295 \\ 110 & 103 & & - \\ 450 & 403 & 386 & 500 \\ 198 & 186 & & - \\ 105 & 140 & & - \\ 106 & 110 & & - \\ 101 & 100 & & - \\ 106 & 144 & & - \\ 80 & 120 & & - \\ 30 ? & 80 & & - \\ 73 & 67 & & - \\ & & & \\ 440 & 286 & & - \\ & 230 & & - \\ & & & \end{array}$

Column 1 - Tasmanian specimen

2 - South African specimen

3 - Specimen of Fraser (1945)

4 - South Australian specimen. 

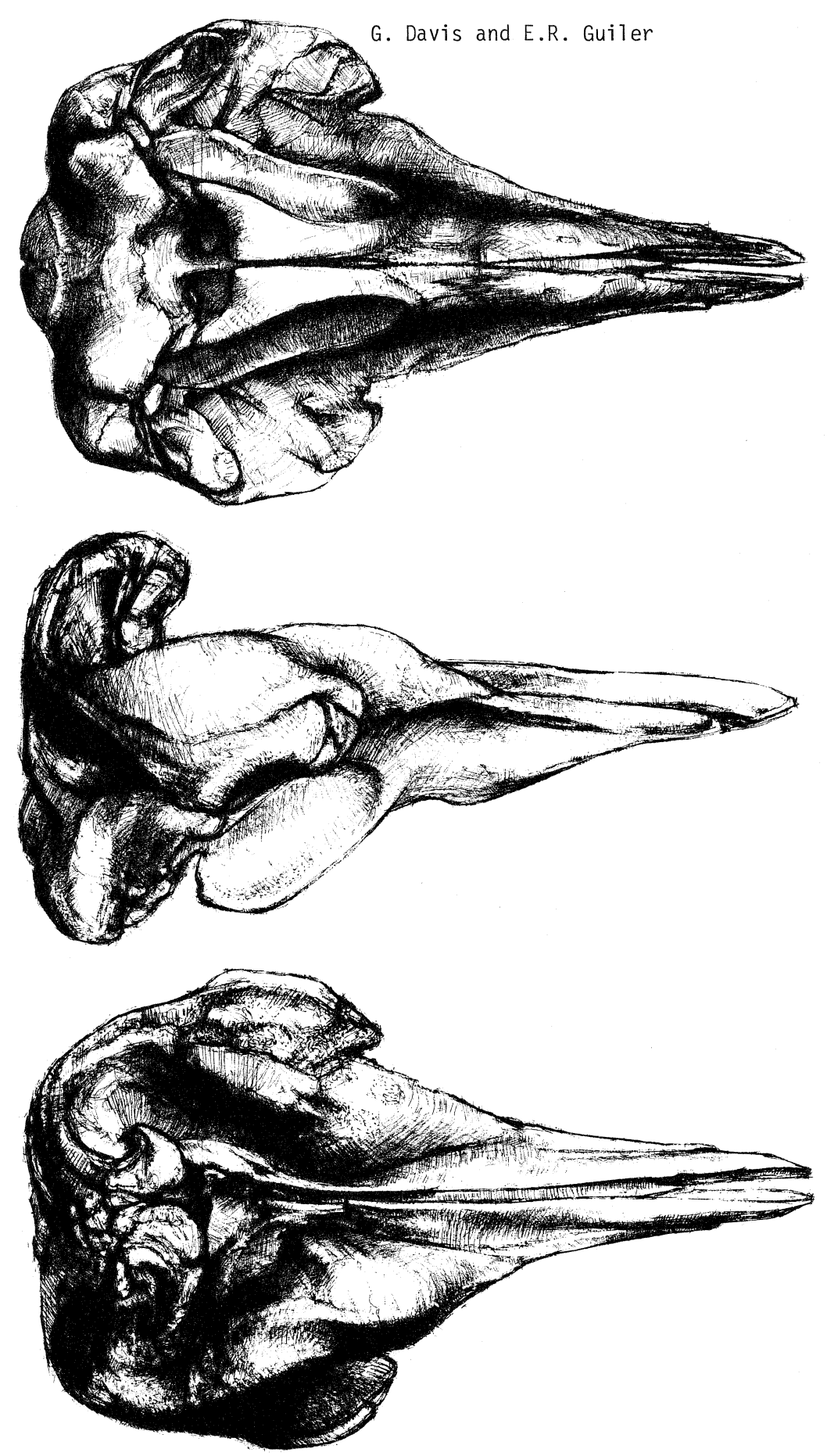

FIG. 1 - Skull of Hyperoodon planifrons found on Ocean Beach, Strahan, Tasmania. 
The greatest width of the occipital condyle as well as the width of the foramen magnum is greater than in the South African specimen whereas the wider occipital condyle is smaller. The relative width of the nasal bones is also greater in the Tasmanian animal.

The mesorostral canal was not filled by ossified material which the authors believe suggests that the specimen was a female, although Nishiwaki \& Kamiya (1958) reported that the type specimen of Mesoplodon ginkgodens, another ziphiid, although believed to be a male had a nearly empty mesorostral canal.

\section{DISCUSSION}

Very little is known of the biology of this species unlike its boreal counterpart H. ampulzatus, which is the subject of a fishery (Mitchel1 1975). The southern Hyperoodon has been seen in a small school of about six individuals by one of the authors (E.R.G.), although Bruyns (1971) saw a group of 40 whales which he believed to be of this species.

The species is reported from Chile (Bruyns 1971, Donoso Barros 1975), Buenos Aires and Patagonia (Moreno 1895), North Island of New Zealand (Waite 1913), Timaru (McCann 1961), Falkland Islands (Hamilton 1952), northwestern Australia (Flower 1882), South Australia (Hale 1931), Victoria (Wakefield 1967), South Africa (Tietz 1966), South Orkney and South Georgia Islands (Fraser 1945). Observations have been made at sea in the Southern Ocean by Tomilin \& Latyschev (1967) (quoted in Browne11 1974), and by one of the authors (E.R.G.), who saw a group of between five and seven whales in 1 at. $65^{\circ} 36^{\prime} \mathrm{S}$, long. $75^{\circ} 40^{\prime} \mathrm{E}$ on 2nd January 1980 .

The species clearly is circumpolar in distribution extending from the Southern Ocean as far north as latitude $30^{\circ} \mathrm{S}$ in all of the oceanic masses. The type locality from the Dampier Archipelago (1at. $21^{\circ} \mathrm{S}$ ) extends the range into the tropics but as this is the only such report it may, in the absence of further records from so far north, be regarded as a vagrant.

The discovery of this skull brings the total number of ziphiid whales positively recorded from Tasmania to eight. The only species which may have a circumpolar distribution but has not been recorded in Tasmania is Tasmacetus shepherdi which has been recorded very few times and never yet been recorded alive. The Tasmanian ziphiids represent not only the cosmopolitan and austral circumpolar species but also the tropical Mesoplodon densirostris (Guiler 1978).

\section{ACKNOWLEDGEMENTS}

We are indebted to Mr M. Schultz of Monash University and to Mr H. Wapstra, National Parks and Wildlife Service for the information leading to the recovery of the skull.

\section{REFERENCES}

Brownell, R.L., 1974: Small Odontocetes of the Antarctic. Antarctic Map Folio Series: Antaretic Marmals. Folio B.

Bruyns, W.F.J.M., 1971: FIELD GUIDE TO THE WHALES AND DOLPHINS. Amsterdam.

Donoso Barros, R., 1975: Contribucion al conocimiento de los cetaceos vivientes y fosiles del territorio de Chile. Gayana, 36: 1-127.

Flower, W.H., 1882: On the cranium of a new species of Hyperoodon from the Australian Seas. Proc. zool. Soc. Lond., 1882: 392-396.

Fraser, F.C., 1945: On a specimen of the Southern Bottle-nosed Whale, Hyperoodon planifrons. Disc. Rep., 23: 19-36.

Guiler, E.R., 1978: Whale strandings in Tasmania since 1945 with notes upon some seal reports. Pap. Proc. Roy. Soc. Tasm., 112: 189-213.

Hale, H.M., 1931: Beaked whales - Hyperoodon planifrons and MesopZodon Zayardi - from South Australia. Rec. S. Aust. Mus., 4: 291-306.

Hamilton, J.E., 1952: Cetacea of the Falkland Islands. Comun. Zool. 4, Mus. Hist. Nat. Montevideo, $4(66): 1-6$. 


\section{Southern Bottle-nosed Whale in Tasmanian Waters}

McCann, C., 1961: The occurrence of the Southern Bottle-nosed Whale, Hyperoodon planifrons, in New Zealand waters. Rec. Dom. Mus., 4(3): 21-27.

Mitchell, E., 1975: PORPOISE, DOLPHIN AND SMALL WHALE FISHERIES OF THE WORLD. I.U.C.N. Monogr. 3.

Moore, J.C., 1968: Relationships among the living genera of beaked whales with classifications, diagnoses and keys. Fieldiana: Zoology, 53(4): 209-298. 1972: More skull characters of the Beaked Whale Indopacetus pacificus. Fieldiana: Zoology, 62: 1-19.

Moreno, F.P., 1895: Nota sobre los restos de Hyperoodon conservados en el Museo della Plata. Ann. Mus. de la Plata, Sec. Zool., III.

Nishiwaki, M. \& Kamiya, T., 1958: A beaked whale, Mesoplodon, stranded at Oiso Beach, Japan. Sci. Rept Whates Res. Inst. Tokyo, 13: 53-84.

Tietz, R.H., 1966: The Southern Bottlenosed whale, Hyperoodon planifrons, from Humewood, Port Elizabeth. Ann. Cape Prov. Mus., 5: 101-107.

Tomilin, A.G. \& Latyschev, V.M., 1967: New data on the flat-fronted bottlenose Hyperoodon planifrons (Flower). Moskov. Obsheh. Ispytatelei Prirody Byulz. otd. Biol., 72: 119-122.

Waite, E.R., 1913: A supposed occurrence of the Bottlenosed Whale in New Zealand. Rec. Canterbury Mus., 2: 23-26.

Wakefield, N.A., 1967: Whales and dolphins recorded for Victoria. Vict. Nat., 84: 273281. 